\title{
PHYSICS AND ASTROPHYSICS AT THE IMPERIAL COLLEGE
}

\section{By PRof. HERBERT DINGLE}

$\mathrm{D}^{2}$ URING the past hundred years, the Colleges now amalgamated in the Imperial College of Science and Tochnology have been prominently associated with both the dissemination and the aequisition of knowledge in the physical sciences. The Royal School of Mines numbers among its professors of physies men like Stokes (1854-60) and Tyndall (1860-68), whose names stand in the forefront of Victorian physies and whose influence on their students, less easy to appraise than their personal contributions to research, was no less important in the maintenance and development of physical science on both its theoretical and practical sides. Tyndall was succeoded by Guthrie (1868-86), whose creation of the Physical Society of London (now the Physical Society, one of the most active and influential scientific societies in the country) in 1873 places him among the greatest benefactors whom this departmont of science has known. The Society, which at first met in Guthrie's rooms at South Konsington, later met regularly at the Royal College of Science and still continues frequently to do so. Its membership has a steady source of supply in the graduates of the College, and the association indeed is so intimate that there is scarcely an activity of the Society in which the College cannot claim some measure of participation.

A comparable influence is that of Mr. (later Sir) Norman Lockyer who, by his founding of Nature in 1869 , provided a much-needed medium through which men of science could communicate to one another and to the world generally the results of their researches. After fifty years of continuous service, Lockyer passed on the office of editor to his former pupil Gregory (now Sir Richard Gregory, Bart.) who received his early training, and later assisted with the teaching, at the Royal College of Science. Gregory edited Nature for twenty years, so that for seventy of the last hundred years it may be said in this place without lack of modesty that the leading scientific journal of the world was established and guided by men whose scientific activities are part of the history of the Royal College of Science.

When, in 1868, Lockyer sprang overnight into fame by the dramatic circumstances of his discovery of the nature of solar prominences and the consequent birth of the science of solar physics, he was not a member of the College staff but a clerk in the War Office. $\mathrm{H}_{\theta}$ immediately established relations, however, with the College which he was later to adorn by entering into collaboration with Frankland, then professor at the College of Chemistry in Oxford Street, the foundation of which in 1845 makes the present year the centenary year of the Imperial College*. Lockyer had observed in the spectrum of the solar prominences and of the chromosphere, which he discovered and named, the lines of hydrogen and also an unknown yellow line which he was anxious to identify. $\mathrm{He}$ realized at once that thenceforth astronomical and laboratory observation must go hand in hand, and with Frankland's assistance he inaugurated a programme of research of the type which is now universally recognized as indispensable to the successful study of astrophysics. They worked in the evenings - the only time during which Lockyer was free-with the assistance of two young men, Pedler and McCleod,

- See also Nature of Nov. 3, pp. 518-527. who later themselves became distinguished as Sir Alexander Pedler and Prof. H. McCleod. The physical conditions in the chromosphere were deduced from the characteristics of the spectrum lines of hydrogen in the light of the changes which had to be made in the laboratory to produce those characteristics. The yellow line, however, could by no means be produced, and Lockyer soon came to the conclusion that it arose from an unknown element, to which he gave the name 'helium'. Not for twenty-seven years was helium discovered on the earth ; but in the meantime Lockyer had learned a great deal about its character from a study of its behaviour in the sun (other lines besides the yellow one were soon recognized as prob. ably arising from the same source), and to-day it is generally acknowledged that the importance of helium in the scheme of things would be difficult to exaggerate.

In 1870, a Royal Commission under the chairman. ship of the Duke of Devonshire was appointed to inquire into the means by which State aid could more effectively advance science and scientific instruction in Great Britain and Ireland. Lockyer was appointed secretary to this Commission, and as one result of its activities the Royal College of Chemistry and the Royal School of Mines were united under the name of the 'Normal Sehool of Science' (later changed to 'Royal College of Science') and established at South Kensington. The Commission sat for five years, and in its final report it expressed the hope that "some arrangement may be made by which the services of Mr. Lockyer in the promotion of science may be secured to the country". The ultimate result of this recommendation was that the Solar Physics Observatory (now transferred to Cambridge) was created under Lockyer's direction at South Kensington, and he was appointed in 1881 as lecturer, and in 1887 as professor, in astronomy at the Normal School of Science. From that time until his retirement from the College in 1901, the activities of the Observatory and of the College were closely connected.

During this period the work at South Kensington stood in the forefront of astronomical physics. Of Lockyer's two outstanding ideas, that of the 'meteoritic hypothesis' - the theory that the heavenly bodies originated in meteors the gradual aggregation and subsequent development of which constitute the evolution of the physical universe-has not stood the test of time; though in some respects-such as the deduction that stars, starting as cool bodies, become hotter and pass through a maximum temperature to a cool state again-it later received on independent grounds a degree of approval for which Lockyer fought vainly in earlier years. The other idea, however-that of 'dissociation'-was truly prophetic. On spectroscopic evidence Lockyer argued, with complete justification, that we must recognize that atoms and molecules are not eternally unchangeable en. tities, but that they can be and are broken up into simpler forms which yield different spectra. The character of the dissociation it was scarcely possible to conceive in the absence of any theory of atomic structure; but on the main point, Lockyer, though he stood almost alone, was perfectly correct.

From 1885 onwards Lockyer had as his assistant Alfred Fowler, a young student of great ability in astronomical and spectroscopic work. Fowler suc. 
ceeded Lockyer in the conduct of the work at the Royal College of Science, and immediately distinguished himself by a succession of identifications of previously unknown features of celestial spectra. The TiO bands in the spectra of red stars, the $\mathrm{CO}$ bands in the spectra of comets' tails, and the 'cosmic hydrogen' lines are outstanding examples. Fowler's real opportunity came, however, when in 1913 Bohr initiated the modern theory of the origin of spectra. Fowler's familiarity with the spectra of the elements and their variation with physical conditions was unrivalled, and he immediately saw in the Bohr theory the explanation of facts with many of which he alone was acquainted. What Lockyer had described as 'dissociation' was now seen to be 'ionization', and the successive spectra of an element which Fowler had sorted out and classified on experimental grounds were identified as spectra of atoms at successive stages of ionization. As the theoretical possibilities of analysis developed, Fowler applied them to his store of experimental data, and for some years the College made outstanding contributions to the most rapidly developing and fundamentally important branch of physical research. Pupils came from various parts of the world, as well as from among College graduates, and, to mention but two examples, Saha's thermodynamical theory of stellar atmospheres and Catalan's discovery of the existence of multiplets originated in Fowler's laboratory. Experimental spectroscopy may truly be said to have been borm and matured at the Royal College of Science. Fowler himself, after his appointment as one of the first Yarrow research professors of the Royal Society, continued to work and direct research there.

Another branch of study in which the College has figured prominently is that of colour physics. This was begun as early as 1877, when Captain (later Sir William) Abney set up his laboratory in one of the temporary buildings at South Kensington which at that time were the only accommodation available to the Normal School of Science. The work has continued until the present time, and now forms an important part of the College's contribution to physical research. Abney's colour-patch apparatus was a pioneering effort in experimental research in this field, and it was applied not only to fundamental investigations but also to the testing of the colour vision of recruits for the Royal Navy and other services in which this physical characteristic is of importance. In photographic work also, particularly in the infra-red, Abney was a pioneer, and his emulsions for this region of the spectrum still defy reproduction. If the story that he photographed a kettle of boiling water in the dark by means of its temperature radiation is authentic, it was at the College that the work was done. In more recent years the Abney apparatus has been superseded by the Wright colorimeter, also a product of the College, and active research is carried on not only into the peculiarities of various types of colour vision, in which valuable assistance is given by the Medical Research Council, but also into many aspects of colour which affect problems of illumination and the dyeing and other industries.

For twenty-one years, from 1876 until 1897, the College was the scene of activity of one of the great experimenters of the time-Mr. (later Sir) C. V. Boys. of his numerous achievements, all bearing the stamp of great ingenuity and experimental skill, it will be sufficient to recall his determination of the constant of gravitation with a small laboratory apparatus; his invention of the radio-micrometer, the most sensitive instrument yet devised for the detection and measurement of radiant energy ; the production and discovery of the properties of quartz fibres which he made by firing white-hot molten quartz with an arrow from a bow ; and the photography of lightning and of bullets in flight. All Boys's work was characterized by the combination of extreme accuracy and sensitivity with compactness of design. His genius was essentially individual and there was no possibility of his founding a school; but he had a keen eye for choosing the right man for a job, and he established a tradition which extends his influence beyond the direct effect of his own achievements.

During the earlier part of the present century, the Physics Department was under the direction of the late Prof. H. L. Callendar, whose work in temperature measurement and various other branches of heat and thermodynamics has become classical. The present chairman of the Governing Body, Lord Rayleigh (then the Hon. R. J. Strutt), was also at that time a professor of the College, and carried out much of his well-known work on radioactivity and discharges in gases. Callendar, like Boys, had a genius for exact measurement, and under his guidance and that of his collaborator, Prof. W. Watson, a succession of students received a training in habits of precision which has had no small influence on the successful application of physics to industrial affairs during the last forty years. It would be difficult to estimate, for example, how much Callendar's example and influence have contributed to the achievements of the National Physical Laboratory since its establishment. Some of the most outstanding members of the staff of that institution owe their physical knowledge and methods of research to his training.

During Callendar's professorship, the practice was begun of establishing sub-departments of the Physics Department for the advancement of certain specialized subjects. Astrophysics, already mentioned, became after Lockyer's retirement one such department which is still very active, and a Technical Optics Section was later added. This Section originated during the War of 1914-18 as a separate department, intended to be a source of production of optical designers, the lack of whom in the country during the War was felt as a serious disability. It was later brought under the general control of the head of the Physics Department, and it now covers a wide field of research and training in various aspects of optical work. An associated sub-department of Instrument Design has performed a useful function, and its reorganization as an independent department is now under consideration. Meteorology has pursued the opposite course to technical optics. Beginning in 1920 as a branch of physics, with a part-time chair, which has had such distinguished occupants as the late Sir Napier Shaw and Sir Gilbert Walker, it became a separate department in 1934 with a full-time professorship. Courses are given to students who have graduated in physics at the College or have had an adequate training elsewhere, and research into various problems of climate and weather is carried on. The most recently established sub-department is that of Geophysies, where, in the only postgraduate school of its kind in the country, students are trained in the principles of prospecting and other geophysical work.

Under the present head of the Department of Physics, Sir George Thomson, research in electron diffraction and nuclear physics is conducted. This is 
so much a matter of common and vital interest at the present time that it needs no emphasis here. The work of the College was specifically mentioned in Mr. Churchill's original statement on the atomic bomb, when fcr the first time the leading part played in the matter by Sir George Thomson's Committee was made known. Physics at the Imperial College begins its second century in most auspicious circum. stances, and, granted the support to which its record entitles it, the future should witness no abatement of its influence both in pure research and in the application of physical knowledge in the widest possible field.

\section{NEWS and VIEWS}

\section{Atomic Energy and Scientific Freedom}

SrNCE the opinions on atomic energy expressed in the leading article beginning on p. 547 were written, several important pronouncements in this connexion have been made. In the past, statements have been published from many sources and some of these, especially those attributed to Mr. Truman, have not only misled the general public, but have also caused irritation to many men of science in general and those who have kept in touch with research in atomic physics, especially since 1934, in particular. M. Molotov's claim in his speech in Moscow, on November 6, that the Soviet Union will soon "have atomic energy and many other things" will come as no surprise to men of science. On the other hand, it will probably stimulate second thoughts in others (and there are many) who have been inspired to believe that while the so-called 'secrets' of the atomic bomb remain vested in Britain, the United States and Canada, the world is safe.

Prof. M. L. Oliphant's vigorous speech at Birmingham on November 3 was also timely. As he stated, it is not possible to "deal with this job by a secret meeting between Mr. Attlee and President Truman. This is so big, so important, and so vital to the world, that it has to be done in the open". The recent statement from the Soviet Union confirms Prof. Oliphant's view that the value of the 'secret' held by the Allies is about six months effort on the part of any industrial country. A more vigorous and concerted effort on the part of all men of seience to keep soience free and intercourse between men of science open and world-wide is essential if the science of atomic energy, and most probably other branches of science eventually, are not to sink into the slough of international political intrigue. Science must not be allowed to become a tool in the hands of anyone, certainly not a part of any nation's foreign policy, for if ever it does then the consequences may prove to be the most serious in the history of science, indeed of the world.

At a joint conference of the World Unity Movement and the Council for World Airways (both organizations with offices at 20 Buckingham Street, London, W.C.2) held at the City Literary Institute, London, on November 2, Sir Leonard Hill, Prof. Lancelot Hogben, Dr. Kathleen Lonsdale, Prof. Lionel Penrose and $\mathrm{Mr}$. Ritchie Calder, among others, spoke on the implications of the recent developments of atomic energy in relation to international affairs and the freedom of science. The following resolution, moved by Mr. Caradog Jones, was passed by the meeting : "Believing that no scientific knowledge should or can willingly be kept secret this Conference urges that the development of atomic energy be made subject without delay to international control and that the advice and co-operation of scientists be sought in order to devise the best means to exploit its use under a world authority solely and fully in the interest of the world community".

\section{Nobel Laureates in Medicine}

MwN of science will welcome the announcement that the Nobel Prize for Medicine for 1945 has been awarded jointly to Sir Alexander Fleming, Sir Howard Florey and Dr. E. Chain. Sir Alexander Fleming is now professor of bacteriology in St. Mary's Hospital Medical School, London. During the First World War, when he was working upon the bacteriology of septic wounds, Fleming became convinced that the chemical antiseptics then in use were often very harmful to the leucocytes which attack bacteria, and he discovered, in 1922, lysozyme, an antibacterial ferment which occurs in many animal tissues and secretions. In 1924 he showed that, if the antileucocytic power of an antiseptic is greater than its antibacterial power, it is not likely to be therapeutically valuable. When, therefore, he published in 1929, six years before the announcement by Domagk of the discovery of the sulphonamides, the discovery of penicillin and an account of his early trials of its antibacterial action, it was evident that he had provided us with an antibacterial agent which was not only powerfully antibacterial against some of the most pathogenic of organisms, but was also not toxic to the all-important antibacterial leucocytes and also not toxic to the animal infected with them. Attempts made at that time, however, to extract a form of penicillin which could be used therapeutically were not successful, and it seemed that this remarkable antibacterial agent would be denied to man.

The stage had, nevertheless, been set for the later work at Oxford of Sir Howard Florey and Dr. E. Chain, and it is interesting to note that the earlier work of these two investigators, like that of Sir Alexander Fleming, had predisposed them to make the particular and all-important contribution to the main problem which they made. Sir Howard Florey is now professor of pathology in the University of Oxford. Since the 1920's he has been interested in problems of bacterial inhibition and he has studied Fleming's lysozyme. The original discovery that some organisms produce substances which inhibit or prevent the growth and multiplication of other organisms was made by Pasteur and Joubert in 1877, and in 1899 Fmmerich and Loew had extracted pyocyanase from $B$. pyocyaneus. When the Oxford work on antibiotics began in 1938, pyocyanase and penicillin were selected for study. Florey now had at hand the assistance of Dr. E. Chain, University demonstrator in chemical pathology at the Sir William Dunn School of Pathology, a man whose studies of enzymes and of the isolation from natural sources of substances which are physiologically active has earned him distinction. Dr. Chain (though of Russian extraction) was born in Berlin and received his early training at the University there. He came to Britain in 1933 and was appointed to the staff of the Sir William Dunn School of Pathology in 1935.

The success of this collaboration is now well known. 